\title{
Relationship between Individual Characteristics and Social Entrepreneurial Intention: Evidence from Bangladesh
}

\author{
Md. Uzzal Hossain ${ }^{\text {a }}$
}

Abstract: Taking the theory of planned behavior as a basis, this study investigates the role of individual characteristics on social entrepreneurial intention (SEI). More specifically, this study has examined the impact of risk-taking tendency, locus of control, self-efficacy, empathy, and prior experience on the inclination process to become a social entrepreneur. Using systematic random sampling, data were collected from 336 Bangladeshi university students with an average age of 23. The survey was conducted based on a structured questionnaire consisting of 20 items. Correlation analysis and multiple regression analysis were conducted to test the relationship among variables and check the hypotheses. The results showed significant positive relationships among variables, and self-efficacy, locus of control, risk-taking propensity, prior experience, and empathy significantly influenced students' intention to be future social entrepreneurs. The current study contributes to the social entrepreneurship literature by incorporating risk-taking tendency and locus of control to SEI research and validating previous findings in the Bangladeshi context. The research outcome may facilitate academicians to create a psychological support system for students that can promote social entrepreneurship in Bangladesh.

\author{
Keywords: Social \\ Entrepreneurial Intention, \\ Locus of Control, Self- \\ Efficacy, Empathy, Risk Taking \\ JEL: L31, L20
}

\section{Introduction}

Entrepreneurship is an influential factor in economic and social development. It creates job opportunities, provides unique solutions, improves the standard of living, reduces poverty, utilizes resources effectively and effectively, and generates social and economic value (Kelley, Singer \& Herrington, 2016). Carland, Hoy, Boulton, and Carland (1984) have defined an entrepreneur as "an individual who establishes and manages a business for the principal purposes of profit and growth." Entrepreneurs start a venture, bear the risks, and enjoy the business's reward (Handy, Ranade \& Kassam, 2007). According to Tracey and Phillips (2007), social entrepreneurship is "the creation of an enterprise that has a social purpose, and thus, it involves both commercial viability and social construction." Social entrepreneurship is concerned with providing creative solutions to address problems in education, climate, fair trade, nutrition and civil rights, gender rights, and environmental issues. Social entrepreneurs are change agents (Sharir \& Lerner, 2006) who always search for opportunities and provide unique and innovative solutions to address unmet social needs. They are motivated by different goals to generate social and economic value (Nga \& Shamuganathan, 2010). They are the key players in bringing essential services and solutions to the untouched areas of our society. Social entrepreneurs are different from commercial ventures. Commercial entrepreneurs' primary purpose

a Asst. Prof., Bangabandhu Sheikh Mujibur Rahman Science \& Technology University, Business Studies Faculty, Department of Management Studies, Gopalganj, Bangladesh, uzzal.mgt@bsmrstu.edu.bd (ORCID ID: 0000-0001-7596-3408) 
is to earn a profit, whereas social entrepreneurs focus on solving community problems and generating revenue. Investigating the inspiration and factors contributing to entrepreneurial intention is an excellent way to understand and forecast entrepreneurship (Krueger, Reilly \& Carsrud, 2000). Thompson (2009) defined entrepreneurial intention as the "self-acknowledged conviction by a person that they intend to set up a new business venture and consciously plan to do so at some point in the future."

The journey of social entrepreneurship started with the private sector's emergence and growth (Tiwari, Bhat \& Tikoria, 2017). Even though business organizations, the public sector, government, international cooperation, and nonprofit organizations were meeting social needs, social inequalities still prevail, especially in developing countries like Bangladesh. Bangladesh is one of the pioneering countries for the concept of social entrepreneurship (Bornstein \& Davis 2010). Fazle Hasan Abed has established the world's largest non-government organization called BRAC to eradicate poverty, empower women, ensure social equality and provide education for poor people all over the world. Muhammad Yunus has brought a new concept by giving small loans to poor people to make entrepreneurs (Yunus, Bank, Yunus, Prize \& Bank, 2006). Although Bangladesh is well known for some of the renowned social entrepreneurs, research in social entrepreneurship is still rare. Few studies have been conducted compared to its importance to the economy. Most of the social entrepreneurship literature has mainly come from European or developed economies (Tiwari, Bhat \& Tikoria, 2019). For employment and social purpose, Bangladesh needs more social entrepreneurs who will contribute to the standard of living. That is why this study intends to examine what individual factors influence Bangladeshi students to become future social entrepreneurs.

Commercial entrepreneurship is the process of starting and managing business functions that depend on market exchange structures to maximize profit (Estrin, Mickiewicz \& Stephan, 2016). Austin, Stevenson, and Wei-Skillern (2012) defined social entrepreneurship as "innovative, social value-creating activity that can occur within or across the nonprofit, business, or government sectors." Commercial and social entrepreneurship have some common grounds as both create employment, ensure economic development, require innovative solutions, involves risk and proactiveness (Vivarelli, 2013; Estrin et al., 2016). Also, there is a notable difference between the two in terms of market failure, purpose, mobilization of financial and human resources, and social impact measurement (Austin et al., 2012). Commercial ventures' mission is to maximize the return that may not necessarily alleviate poverty, exclusion, and discrimination, laying the foundation for social entrepreneurship. As commercial entrepreneurship's purpose and nature are not the same as social entrepreneurship, it is expected that social entrepreneurs require different skills than commercial entrepreneurs. Compared to entrepreneurial intention and individual-level factors, social entrepreneurial intention (SEI) studies are very few concerning individual characteristics. For this reason, this study has selected unique personality characteristics to measure SEI.

SEl is defined as the determination and readiness of an individual to start a social venture to solve social problems using innovative techniques (Prieto, 2010). Several studies have been conducted to understand the determinants of SEI from a different context (e.g.; Yang, Meyskens, Zheng \& Hu, 2015; Tiwari et al., 2017; Hockerts, 2017; Peng, Hassan, Akhtar, Sarwar, Khan, \& Khan, 2019; Akhter, Hossain \& Al Asheq, 2020). Most of these researchers have identified empathy, moral obligation, social support, educational program, self-efficacy, personality traits, and prior experience as the main determinants of SEI (Hsu \& Wang, 2017; Hockerts, 2017; Bacq \& Alt, 2018; Ip, Liang, Wu, Law \& Liu, 2018; Peng et al., 2019). These studies have considered both individual and situational factors together to measure SEI. A systematic literature study by Tan, Le, and Xuan (2019) has found that SEI research falls under four categories. The first category focused on understanding the concept of social entrepreneurship; the second category concentrated the study on personality level variables; the third category emphasized situational factors, and the last type studied intention behavior linkage. The study of Nga and Shamuganathan (2010), Kedmenec, Rebernik, and Peric (2015), Chipeta and Surujlal (2017), Tiwari et al. (2017), Bacq and Alt (2018), and Lacap, Mulyaningsih, and Ramadani (2018) have focused on individual-level characteristics to understand SEl. Whereas the research of Hockerts (2017), Ip et al. (2018), Peng et al. (2019), and Hsu and Wang (2019) have focused on a mix of both individual and situational factors to determine SEI. Very few studies have solely focused on contextual factors. Out of the four categories of research, this study has selected only individual-level factors. 
Risk-taking propensity and locus of control are individual-level variables that are commonly studied in the commercial entrepreneurship literature (Mazzarol, Volery, Doss, \& Thein, 1999; Altinay, Madanoglu, Daniele \& Lashley, 2012; Yukongdi \& Lopa, 2017). Studies focusing on measuring the impact of risk-taking tendency and locus of control on SEI are rare. Finding the gap, this study focuses on determining the effect of risk-taking propensity and locus of control on SEI. It is expected that this study will make an excellent contribution to the personal level variable category as it incorporates risk-taking tendency and locus of control factors to mentioned category. Individuals may think about opportunities, but everyone cannot convert those prospects into a successful venture. Additionally, this study incorporates risk-taking propensity and locus of control into SEI research. Specifically, this article intends to measure; (1) how empathetic people feel the need of the socially lagged people and respond to address the issues by creating a social venture, (2) whether previous experience to work on a voluntary project determines SEI, (3) whereby belief on self-effort to success or failure predicts social entrepreneurship, (4) how risk-taking behavior envisions SEI, and (5) whether confidence on personal skills influences SEI.

\section{Relevant Literature and Hypothesis Development}

\subsection{Social Entrepreneurial Intention}

The planned behavior theory suggests that an individual's actions can be anticipated from his subsequent intentions (Ajzen \& Fishbein, 1970). The purpose is a condition that drives an individual toward a particular goal (Bird, 1998). Intention can be regarded as a precondition governing expected actions (Souitaris, Zerbinati \& Al-Laham, 2007). Entrepreneurial intent refers to an individual's determination to some future actions that are predicted to start a venture or an organization (Kruger \& Brazeal, 1994). Expectations to do something or guiding behavior to a particular task are the main building blocks in anticipating expected actions (Krueger \& Brazeal, 1994). SEI can be defined as employing human beings' psychological behavior that induces them to gain knowledge, understand ideas, and launch social business plans to turn out to be a social entrepreneur (Mair, Robinson \& Hockerts, 2006). An individual determines to identify the social need and apply a unique solution to address the issue to generate financial returns. It is presumed that the determination to start a social venture laid the foundation to create a social business. The unification of actual entrepreneurial opportunity is intentionally aligned behavior.

\subsection{Empathy}

Empathy is defined as an individual's ability to understand others' feelings (Preston et al., 2007) and the inclination to retaliate against others' mental state compassionately (Goetz, Keltner, \& Thomas, 2010). Empathy can be cognitive or affective (Smith, 2006). Cognitive empathy is about understanding others' feelings (Gallup \& Platek, 2002), whereas affective empathy means emotional response to other mental states (Macaskill, Maltby \& Day, 2002). Empathy is a crucial individual-level trait of a social entrepreneur (Dess, 2012) and a key influential factor of social entrepreneurial behavior (Hockerts, 2015). Mair and Noboa (2006) stated that the purpose of social entrepreneurship is "the innovative use of resource combinations to pursue opportunities aiming at the creation of organizations and/or practices that yield and sustain social benefits." It means that social enterprises need individuals who have helping behavior to people and society. As empathetic people most likely behave in a way that benefits others, it can predict SEI (Mair \& Noboa, 2006). Empathy in social entrepreneurship means being aware of unprivileged people's feelings or problems and responding to the need for innovative solutions (Hockerts, 2015). Even though empathy may ignite meaningful social change, it is not expected that all empathetic people will become potential social entrepreneurs (Ersnt, 2011). As potential social entrepreneurs are expected to be compassionate to the need of others and make a real impact by taking appropriate actions, the following hypothesis can be formulated:

\section{$\boldsymbol{H}_{1}$ : Empathy positively influences social entrepreneurial intention.}




\subsection{Prior Experiences}

Experience with something may create a good or bad feeling about work. Good experience with something reinforces the behavior to repeat the action. Previous experience is a determinant of prosocial behavior (Vining \& Ebreo, 1989). The definition of prior experience may vary from context to context. For example, in a commercial venture, an entrepreneurial family may induce another family member to start another commercial venture. Or previous work experience in a commercial firm may influence an individual to start another commercial enterprise. But in social entrepreneurship, the scenario can be different due to the difference in purpose and nature of business. A potential social entrepreneur may want to launch a social venture after working as a volunteer for a nonprofit organization or in a social enterprise. Earlier studies have shown that prior experience is a good predictor of entrepreneurial intent for commercial ventures (Shook, Priem, \& McGee, 2003; Kautonen, Luoto \& Tornikoski, 2010; Chlosta, Patzelt, Klein \& Dormann, 2012). The prior experience here refers to having a practical contract with voluntary activities and behaviors and actions that benefit disadvantaged people. The study of Hockerts (2017) and Akhter et al. (2020) have found prior experience is an influential factor of SEl. It can be perceived that people who have previous experience dealing with social works and voluntary activities are more inclined to choose a social entrepreneur as a career choice. Based on the evidence, the following hypothesis can be predicted

\section{$\boldsymbol{H}_{2}$ : Prior experience positively influences social entrepreneurial intention.}

\subsection{Locus of Control}

Locus of control is an individual personality trait and an essential characteristic of an entrepreneur (Venkatapathy, 1984). Locus of control refers to the belief of an individual that regulates and controls the outcome of anything (Rotter, 1954). It has two dimensions in which internal locus of control refers to an individual controlling the outcome of success and failure. The other type, external locus of control, means that fate, context, and chance determine the outcome other than an individual's effort (Rotter, 1966). People who score high in an internal locus of control believe that their actions and outcome are the outcome of their effort and hard work other than fate or chance. An Individual's perception to influence life events is crucial to select a future career. Previous studies on commercial entrepreneurship revealed that internal locus of control substantially influences entrepreneurial intention (Goksel \& Aydıntan, 2011; Altinay et al., 2012). The dual nature of earning profit and serving society makes business management a tricky task for social entrepreneurs. Social entrepreneurs need to believe that they can substantially change society with their innovative solutions and efforts. Individuals with a higher locus of control are supposed to be entrepreneurial in nature as they are deemed to be more achievement oriented (Diaz \& Rodriguez, 2003). So, it is expected that social entrepreneurs should possess a higher locus of control to start a future social venture. we can construct the following hypothesis

$\boldsymbol{H}_{3}$ : Internal locus of control positively influences social entrepreneurial intention.

\subsection{Self-Efficacy}

The term self-efficacy came into the limelight when Bandura (1977) used the concept in social learning theory. Self-efficacy is defined as an individual's belief regarding his/her ability to accomplish a particular task (Bandura, 1999). It refers to a conviction about one's personal capability to complete a job or a specific set of activities (Bandura, 1999). It affects an individual's decision-making process and is regarded as a good predictor of career selection (Bandura, 1999). Self-efficacy envisions opportunity identification. Thus, it is always advisable to study it regarding entrepreneurial intention phenomena (Krueger \& Brazeal, 1994). Entrepreneurial self-efficacy is described as the degree to which an entrepreneur believes his/her skills, knowledge, and capabilities to start a new business venture (Sanchez, 2013). Mair and Noboa (2006) suggested that a "high level of self-efficacy allows a person to perceive the creation of a social venture as feasible, which positively affects the formation of the corresponding behavioral intention." The study of Ernst (2014) showed a positive relationship between self-efficacy and attitude towards becoming a social entrepreneur. People with a higher level of self-efficacy are supposed to be more confident about their skills, 
which may help them take the innovative initiative to do something for society. Social entrepreneurs provide unique solutions to unmet social needs. The task is not easy as they have to search for answers that are unserved and unsolved. Earning profit while creating social value is a much more difficult task than just focusing on generating profit (Estrin et al., 2016). Self-belief is an act that is the fundamental human motivation (Ryan \& Deci, 2000), and this motivation should be satisfied for social entrepreneurship setting to become a social entrepreneur (Bacq \& Alt, 2018). Due to this, social entrepreneurs should have higher self-confidence about their capabilities compared to commercial entrepreneurs. Based on the literature support, the following hypothesis can be formed:

$\boldsymbol{H}_{4}$ : Self-efficacy positively influences social entrepreneurial intention.

\subsection{Risk-Taking Tendency}

Risk-taking is a personality trait of an individual. Some people are eager to take the risk; some take moderate risks while others do not like to take any risks. The risk-taking tendency is the propensity of an individual to take a chance in decision-making. According to Brockhaus (1980), risk-taking tendency is defined as "the perceived probability of receiving rewards associated with the success of a situation that the individual requires before he will subject himself to the consequences associated with failure, the alternative situation providing less reward as well as less severe consequences than the proposed situation." Compare to non-entrepreneurs; entrepreneurs have a higher tendency to take the risk (Stewart Jr, Watson, Carland \& Carland, 1999). Risk-taking entrepreneurs are perceived as more capable of managing complex situations (Stewart \& Roth, 2001). The study of Wijaya (2019) and Hossain, Asheq, and Arifuzzaman (2019) have found that risk-taking propensity is a good predictor of entrepreneurial intention. Like commercial entrepreneurs, social entrepreneurs have to take financial and career risks before starting a social venture. Literature relating to commercial enterprise and the risk-taking behavior of entrepreneurs has been primarily developed. Few studies have concentrated on investigating risk-taking tendency and SEl. The study of Chipeta and Surujlal (2017) has found that risk-taking behavior is a significant positive predictor of becoming a social entrepreneur in South Africa. Based on the above literature, the given hypothesis can be made

\section{$\boldsymbol{H}_{5}:$ Risk-taking tendency positively influences social entrepreneurial intention.}

Based on theoretical framing and proposed hypotheses, the following research framework can be constructed:

Figure 1. Conceptual Model

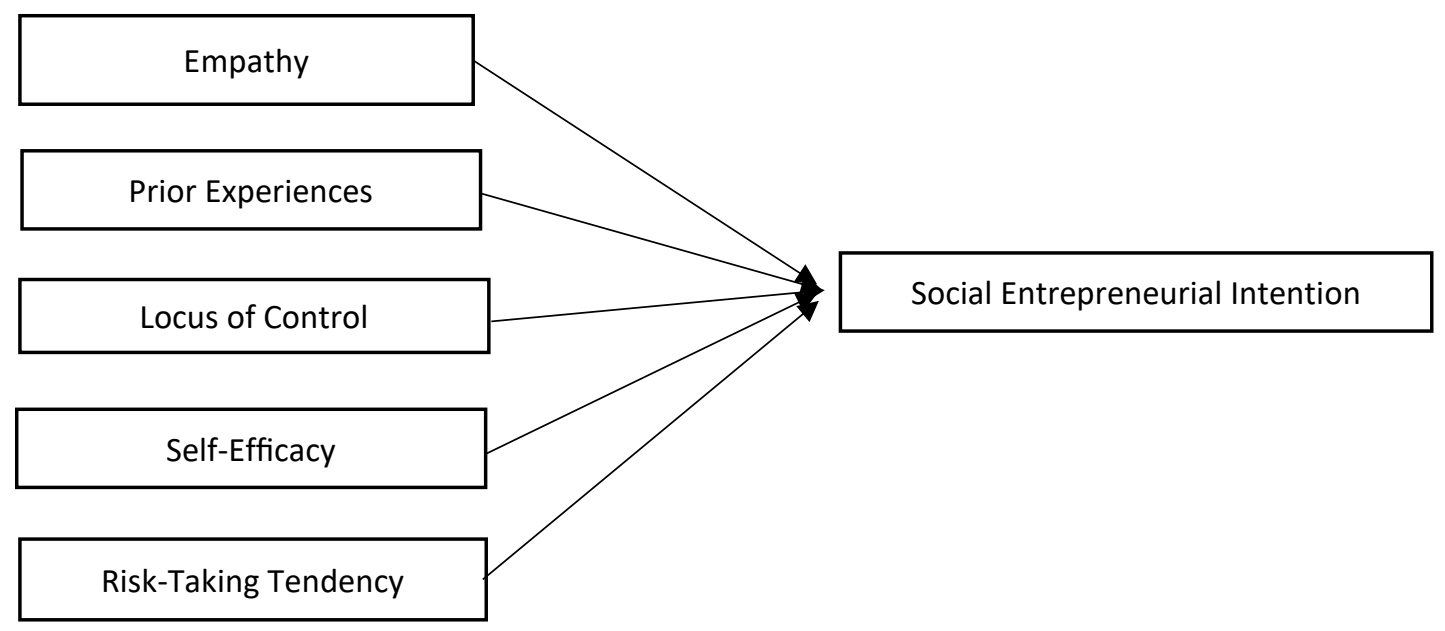




\section{Methodology}

\subsection{Samples and Measures}

This study has explored the role of personal characteristics in SEl. As students are the immediate career chooser, they are most suitable for studying SEI (Krueger et al., 2000). Entrepreneurial intention and SEI research usually take students as respondents (Yang et al., 2015; Tiwari et al., 2017; Hockerts, 2017; Peng et al., 2019; Akhter et al., 2020). Though there are criticisms taking students as samples, they are suitable for the study (Ferber, 1977). A quantitative survey was administered to understand SEI and individual characteristics. A dedicated supervisor administered the survey in the classroom setting before the pandemic (February) in Bangladesh. A brief idea about social entrepreneurship and the purpose of the study was clarified before submitting the questionnaire. Participation in the survey was voluntary. Total 443 feedbacks were collected from the respondents. About 279 business students and 164 nonbusiness students from a public university of Bangladesh participated in the survey with an average age of 23. Out of the collected responses, 336 samples were found useable for this study. The responses were recorded on a 5-point Likert scale where one denotes strongly disagree, and five refers to agree strongly.

Table 1. Demographic Characteristics of Respondents

\begin{tabular}{|l|l|c|c|}
\hline Demographics & Items & Frequency & Percentage \\
\hline \multirow{3}{*}{ Age } & Below 21 & 7 & 2.1 \\
& $21-24$ & 268 & 79.8 \\
& Over 24 & 61 & 18.1 \\
\hline \multirow{2}{*}{ Gender } & Male & 189 & 56 \\
& Female & 147 & 44 \\
\hline \multirow{2}{*}{ Education } & Bachelor & 227 & 68 \\
& Masters & 109 & 32 \\
\hline \multirow{3}{*}{ Background } & Business & 208 & 62 \\
& Social science and humanities & 52 & 15 \\
& Science and engineering & 76 & 23 \\
\hline \multirow{3}{*}{ Religion } & Muslim & 186 & 55.1 \\
& Hindu & 147 & 44 \\
\hline \multirow{2}{*}{ Financial } & Others & 3 & 0.9 \\
\hline \multirow{2}{*}{ Condition } & Lower & 89 & 26.5 \\
& Middle & 193 & 57.5 \\
\hline & Upper & 54 & 16 \\
\hline
\end{tabular}

\subsection{Survey Instruments}

To collect data, a structured questionnaire was prepared. The first part of the questionnaire explained the purpose of the study. A short and clear concept of social entrepreneurship was provided to get an idea about the topic. The measures of the variables were adapted from three sources. To measure internal consistency among items, this study calculated the Cronbach alpha score. A score of more than 0.60 was accepted as suggested by Hair, Black, Babin, Anderson and Tatham (1998).

The SEI construct was adapted from Yang et al. (2015), which had six items. The scale measures the extent to which participants have the propensity to start a social venture in the future. A sample item of the construct was like, "I will make every effort to start and run my venture that helps society." Cronbach alpha for SEI was 0.71 .

The prior experience evaluated the respondents' level of understanding about social organizations and working on social projects. Prior experience was assessed using the 3-item scale of Hockerts (2017). A sample item of previous experience is "I have some experience working with social problems." Cronbach Alpha score for the prior experience was 0.79 . 
Self-efficacy was measured with a 3-item scale of Hockerts (2017). The items were related to the social entrepreneurship viewpoint. The items assess the degree to which respondents have self-belief about their skills. One example of the item is "I could figure out a way to help solve the problems that society faces." The internal consistency score for the entire variable was 0.82 .

The variable locus of control was quantified using the scale items constructed by Koh (1996). The scale had seven items used to measure the degree to which respondents believe that their effort determines their level of success and failure. A sample item was "I cannot wait, and watch things happen; I prefer to make things happen." The internal consistency of all items was 0.82 .

The empathy construct was ascertained by 3 -items from the scale of Hockerts (2017). The three items of empathy construct identified the degree to which individuals are concerned with disadvantaged people's problems. An item for empathy was like, "When thinking about socially disadvantaged people, I try to put myself in their shoes." The reliability score for empathy was found at 0.88 .

The risk-taking construct was measure with the 6-item scale of Koh (1996). This construct assessed respondent's propensity to take the risk. Out of 6 items, one sample item is "I do not mind working under conditions of uncertainty as long as there is a reasonable probability of gains from it for me." The internal consistency score for the construct was 0.70 .

For examining the validity of the constructs, confirmatory factor analysis (CFA) was applied. The Kaiser-Meyer-Olkin value was found 0.767 , which shows an acceptable score for principal component analysis. Bartlett's test of sphericity was found significant $(\chi 2=249.485, \mathrm{df}=15, \mathrm{p}<0.001)$ that indicates that CFA can be computed for the survey data. The total variance experienced was $71.23 \%$ that refers to acceptable validity. The minimum value of factor analysis was found to be 0.61 (Table 2), which is in the range of a satisfactory score (Sharma, 1996).

Table 2. Factor Loading for the Items

\begin{tabular}{|c|c|c|c|c|c|}
\hline Variables & Code & Loading & Variables & Code & Loading \\
\hline \multirow{6}{*}{$\begin{array}{l}\text { Social } \\
\text { Entrepreneurial } \\
\text { Intention }\end{array}$} & SEl1 & 0.722 & \multirow{3}{*}{ Empathy } & EMP1 & 0.767 \\
\hline & SEI2 & 0.827 & & EMP2 & 0.821 \\
\hline & SEI3 & 0.736 & & EMP3 & 0.790 \\
\hline & SEI4 & 0.725 & & & \\
\hline & SEI5 & 0.657 & \multirow{7}{*}{ Locus of Control } & LOC1 & 0.753 \\
\hline & SEI6 & 0.763 & & LOC2 & 0.674 \\
\hline & & & & LOC3 & 0.794 \\
\hline \multirow{3}{*}{ Prior Experience } & PE1 & 0.743 & & LOC4 & 0.610 \\
\hline & PE2 & 0.814 & & LOC5 & 0.686 \\
\hline & PE3 & 0.630 & & LOC6 & 0.699 \\
\hline & & & & LOC7 & 0.729 \\
\hline \multirow{7}{*}{ Risk-Taking } & RT1 & 0.630 & & & \\
\hline & RT2 & 0.779 & \multirow{4}{*}{ Self-Efficacy } & SE1 & 0.691 \\
\hline & RT3 & 0.649 & & SE2 & 0.727 \\
\hline & RT4 & 0.726 & & SE3 & 0.747 \\
\hline & RT5 & 0.812 & & SE4 & 0.673 \\
\hline & RT6 & 0.702 & & & \\
\hline & RT7 & 0.647 & & & \\
\hline
\end{tabular}




\section{Results and Discussion}

\subsection{Correlation Analysis}

Correlation analysis was conducted to measure the interrelationships among four independent (empathy, prior experience, locus of control, self-efficacy, and risk-taking tendency) and one dependent variable (social entrepreneurial intention).

Table 3. Correlation Analysis Among Associated Variables

\begin{tabular}{|l|c|c|c|c|c|c|}
\hline & SEI & EM & PE & LC & SE & RT \\
\hline Social Entrepreneurial Intention (SEI) & 1 & & & & & \\
\hline Empathy (EM) & $0.339^{* *}$ & 1 & & & & \\
\hline Prior Experience (PE) & $0.316^{* *}$ & $0.623^{* *}$ & 1 & & & \\
\hline Locus of Control (LC) & $0.561^{* *}$ & $0.345^{* *}$ & $0.298^{* *}$ & 1 & & \\
\hline Self-efficacy (SE) & $0.356^{* *}$ & $0.282^{* *}$ & $0.432^{* *}$ & $0.353^{* *}$ & 1 & \\
\hline Risk Taking Tendency (RT) & $0.625^{* *}$ & $0.539^{* *}$ & $0.819^{* *}$ & $0.566^{* *}$ & $0.576^{* *}$ & 1 \\
\hline
\end{tabular}

** Correlation is significant at the 0.01 level (2-tailed).

The relation showed a significant positive correlation among associated variables. The highest significant positive correlation $(r=0.625)$ has been found between risk-taking tendency and SEI (Table 3). Locus of control showed a strong positive correlation with SEI $(r=0.561)$. Self-efficacy, prior experience, and empathy showed the almost same level of relationship with SEI $(r=0.356, r=339$, and $r=316$, respectively).

\subsection{Regression Analysis}

Descriptive statistics were applied to clean and interpret data. Using the Shapiro-Wilk score, a normality test was conducted. This study found sig. value of 0.23 , which is greater than 0.05 . It means that the data used for this study is approximately normally distributed as any score greater than 0.05 is considered to be normally distributed (Razali \& Wah, 2011). Besides, the Z value was calculated for skewness and kurtosis using statistics and standard error. The univariate skewness and kurtosis score found for each variable of this study were less than 1.37 and 1.92, respectively. These scores are in between the acceptable score of below 2 for skewness and 7 for kurtosis (Finney \& DiStefano, 2006); the data were assumed as normally distributed.

Multiple regression analysis was applied to test the impact of five predictive variables on SEI. The study's Durbin-Watson score was 2.029 under the acceptable range of 1.5-2.5 (Durbin \& Watson, 1950). The variance inflation factors and tolerance were below two and between 0.1 to 1.0 , which shows that the model does not have a multicollinearity problem (Kutner, Nachtsheim, Neter \& Li, 2004).

Table 4. Results of Regression Analysis Among Associated Variables

\begin{tabular}{|c|c|c|c|c|c|}
\hline \multicolumn{2}{|c|}{ Model } & $\begin{array}{l}\text { Unstandardized } \\
\text { Coefficients }\end{array}$ & $\begin{array}{l}\text { Standardized } \\
\text { Coefficients }\end{array}$ & $\mathbf{t}$ & Sig. \\
\hline \multirow{6}{*}{1} & (Constant) & 1.097 & & 5.436 & 0.000 \\
\hline & Empathy & 0.094 & 0.148 & 2.970 & 0.003 \\
\hline & Prior Experience & 0.046 & 0.043 & 0.923 & 0.046 \\
\hline & Locus of Control & 0.143 & 0.148 & 2.928 & 0.004 \\
\hline & Self-efficacy & 0.152 & 0.141 & 2.742 & 0.006 \\
\hline & \begin{tabular}{|l|} 
Risk Taking \\
\end{tabular} & 0.332 & 0.386 & 11.209 & 0.000 \\
\hline \multicolumn{6}{|c|}{$R=0.600 \quad R^{2}=0.541 \quad$ Sig. $F$ Change $=0.000 \quad$ Durbin-Watson $=2.029$} \\
\hline
\end{tabular}


The analysis indicate that the model is statistically significant $F(5,317)=75.086$ and $p<0.01$ (Table 4). The survey outcome show that the predictive variable contributes 54 percent to the variance of SEl. The findings reveal that empathy $(\beta=0.148 ; p<0.01)$, prior experience $(\beta=0.043 ; p<0.05)$, locus of control $(\beta=0.148 ; p<0.01)$, self-efficacy $(\beta=0.141 ; p<0.01)$ and risk-taking tendency $(\beta=0.386 ; p<0.001)$ are significant determinants of SEI.

\subsection{Discussion}

Till now, very few studies have been conducted to measure the impact of individual characteristics on SEI. This article makes a theoretical contribution to the social entrepreneurship literature by incorporating risk-taking tendency and locus of control to SEI research. The current study explored the impact of five independent variables on SEI. The hypotheses were tested using multiple regression analysis. The first hypothesis was formulated based on the assumption that empathy positively influences SEI. The survey result states that empathy has a significant influence on SEI and confirms the proposition. The work is consistent with prior studies of Hockerts (2017) and Peng et al. (2019). It means that people who have a higher score on empathy positively influence being a social entrepreneur in the future. The findings suggest that to be a potential social entrepreneur, an individual requires a certain level of other-orientation. The study also validates that empathy directly influences SEI.

The second hypothesis was based on the prediction that prior experience positively influences SEI. The survey result confirms the significant positive correlation between prior experience and SEI. And the regression analysis has found that the relation between the two variables is significant. Thus, our hypothesis is accepted. This result is congruent with the previous study of Hockerts (2017), Peng et al. (2019), and Akhter et al. (2020). It means that respondents who have prior experience doing volunteer works and social activities may induce them to become social entrepreneurs in the future. This is because the prior experience provides students the knowledge to work for others. Students may find the joy and meaning of life to help others. This result recommends that students should be encouraged to attend activities that promote social welfare. Associating students with volunteer clubs can induce students to choose social entrepreneurship as a career choice.

The third hypothesis was about the locus of control. It was assumed that an internal locus of control positively influences SEI. The survey result does confirm that locus of control has a significant relation with and impact on SEI. For this, our hypothesis is accepted. In entrepreneurial intention research, Hossain et al. (2019) and Goksel and Aydıntan (2011) found that risk-taking is a significant determinant of SEl. It reveals that potential social entrepreneurs should believe that their self-effort and hard work will determine success and failure. Social issues are unique, complex, and multifaced that require solutions that are difficult to copy (Mander, Wiggering, \& Helming, 2007). Finding unique solutions is not easy to find. Potential social entrepreneurs should believe that there is always a way to solve a problem.

The fourth hypothesis predicted that self-efficacy has a positive effect on SEI. The analysis provided verifiable evidence for the hypothesis. Stronger SEI was expressed by participants who scored high on selfefficacy. The finding confirms the earlier study in social entrepreneurship (Tiwari et al., 2017). In entrepreneurial intention study, self-efficacy has been found as a significant determinant and notably linked to specified employment priorities and career choice (Boyd \& Vozikis, 1994; Mair \& Noboa, 2006; Hockerts, 2015). It reveals that people who have higher self-belief about their capabilities can be potential social entrepreneurs. Strategies should be taken to make students feel confident by appraising efforts, enhancing teamwork and role-playing, providing feedback, and setting task expectations. A study in Hong Kong has found that self-efficacy does not necessarily predict SEl. It was explained that culture and career options might allow students to choose from other available alternatives (Ip et al., 2018).

The last hypothesis assumed that risk-taking tendency positively influences SEI. The correlation analysis result found a positive and significant relation between risk-taking tendency and SEI. The regression analysis validates the hypothesis that risk-taking propensity has a substantial positive impact on SEI. In the entrepreneurial intention study, risk-taking has been a significant predictor of entrepreneurial intent 
(Yukongdi \& Lopa, 2017; Nasip, Amirul, Sondoh Jr. \& Tanakinjal, 2017). It states that potential social entrepreneurs need to have the propensity to take risks while starting a social venture. Entrepreneurial careers always involve a certain level of risk, and social entrepreneurs are not out of the boundary.

\subsection{Practical Implications}

This study gives a good explanation of what inspires the students as potential social entrepreneurs. If governments and universities want to encourage students towards social entrepreneurship, efforts should be made to change students' perceptions toward social entrepreneurship. More importance should be given to training and educational programs at the university level from where students get the foundation for their careers. Improvements in educational teaching methods could be introduced based on the importance of students' autonomy and freedom to increase social entrepreneurship's appeal as a career choice. Role-play, talent-development exercises, and business plan seminars can be organized to enhance students' selfefficacy, empathy, and locus of control. Universities can organize more social enterprise-related activities and workshops to boost the locus of control, self-efficacy, and empathy among students. Initiatives like arranging social business idea competition, running a small business on campus, and providing students to engage in voluntary activities may induce the student to be future social entrepreneurs. These activities may increase the supply of possible social entrepreneurs and others aware of the concept of social entrepreneurship even though they may not be interested in being social entrepreneurs.

\subsection{Theoretical Implications}

The findings of this research study are supposed to contribute to the social entrepreneurship study in different ways. First, the study incorporates risk-taking tendency and locus of control into the SEI domain. The results confirm that individuals who would like to help underprivileged groups, support others and create social value need to take moderate risk and believe that they can control their future outcome. This study shows how individual personality traits can influence social entrepreneurship as a career choice through the conceptual framework. The study can help understand how personal characteristics help understand the intention process to be a social entrepreneur. This research study contributes to the social entrepreneurship pool that is focusing individual-level motivating factors. The findings further validate previous studies conducted in other countries.

\section{Conclusion}

The study has examined to what extent individual-level characteristics influence students' social entrepreneurial intent. The correlation analysis showed a significant positive correlation among risk-taking tendency, locus of control, empathy, self-efficacy, prior experience, and SEI. In the social entrepreneurship literature, very few studies incorporate risk-taking behavior and locus of control as predictors to SEI. The regression analysis reveals that prior experience, locus of control, empathy, risk-taking tendency, and selfefficacy significantly influences SEl, whereas prior experience was insignificant to determine SEl. This study has examined five critical factors contributing to SEl.

Further study may be directed to incorporate other situational variables that are related to SEI. An analysis can then be made to understand whether individual characteristics or situation factors have more influence than others on SEl. The findings of this are based on the survey of a particular university for which the result cannot be generalized, which suggests doing research based on diverse samples. Here, only individual-related factors are considered that may not provide a holistic view of SEl. Considering moderating and mediating variables to SEI research may provide a better understanding of SEI. 


\section{Declarations and Disclosures}

Ethical Responsibilities of Authors: The author of this article confirms that her work complies with the principles of research and publication ethics.

Conflicts of Interest: No potential conflict of interest was reported by the author.

Funding: The author received no financial support for the preparation and/or publication of this article.

Author Contributions: The author confirms sole responsibility for conceptualization and design, data collection, analysis of data and interpretation of results, writing the first draft of the manuscript, and review and editing.

Plagiarism Checking: This article was screened for potential plagiarism using a plagiarism screening program.

\section{References}

Akhter, A., Hossain, M. U., \& Al Asheq, A. (2020). Influential factors of social entrepreneurial intention in Bangladesh. Journal of Asian Finance, Economics and Business, 7(8), 645-651.

Ajzen, I., \& Fishbein, M. (1970). The prediction of behavior from attitudinal and normative variables. Journal of Experimental Social Psychology, 6(4), 466-487.

Altinay, L., Madanoglu, M., Daniele, R., \& Lashley, C. (2012). The influence of family tradition and psychological traits on entrepreneurial intention. International Journal of Hospitality Management, 31(2), 489-499.

Austin, J., Stevenson, H., \& Wei-Skillern, J. (2012). Social and commercial entrepreneurship: same, different, or both? Revista de Administração, 47(3), 370-384.

Bacq, S., \& Alt, E. (2018). Feeling capable and valued: A prosocial perspective on the link between empathy and social entrepreneurial intentions. Journal of Business Venturing, 33(3), 333-350.

Bandura, A. (1977). Self-efficacy: Toward a unifying theory of behavioral change. Psychological Review, 84(2), $191-215$.

Bandura, A. (1999). Social cognitive theory: An agentic perspective. Asian Journal of Social Psychology, 2(1), 21-41.

Bird, B. (1988). Implementing entrepreneurial ideas: The case for intention. Academy of Management Review, 13(3), 442-453.

Bornstein, D., \& Davis, S. (2010). Social entrepreneurship what everyone needs to know. Oxford: Oxford University Press.

Boyd, N. G., \& Vozikis, G. S. (1994). The influence of self-efficacy on the development of entrepreneurial intentions and actions. Entrepreneurship Theory and Practice, 18(4), 63-77.

Brockhaus Sr, R. H. (1980). Risk taking propensity of entrepreneurs. Academy of Management Journal, 23(3), 509-520.

Carland, J. W., Hoy, F., Boulton, W. R., \& Carland, J. A. C. (1984). Differentiating entrepreneurs from small business owners: A conceptualization. Academy of Management Review, 9(2), 354-359.

Chipeta, E. M., \& Surujlal, J. (2017). Influence of attitude, risk taking propensity and proactive personality on social entrepreneurship intentions. Polish Journal of Management Studies, 15(2), 27-36.

Chlosta, S., Patzelt, H., Klein, S. B., \& Dormann, C. (2012). Parental role models and the decision to become selfemployed: The moderating effect of personality. Small Business Economics, 38(1), 121-138.

Dees, J. G. (2012). A tale of two cultures: Charity, problem solving, and the future of social entrepreneurship. Journal of Business Ethics, 111(3), 321-334.

Diaz, F., \& Rodriguez, A. (2003). Locus of control, nAch and values of community entrepreneurs. Social Behavior and Personality: An International Journal, 31(8), 739-748.

Durbin, J., \& Watson, G. S. (1950). Testing for serial correlation in least squares regression: I. Biometrika, 37(3/4), 409428.

Estrin, S., Mickiewicz, T., \& Stephan, U. (2016). Human capital in social and commercial entrepreneurship. Journal of Business Venturing, 31(4), 449-467.

Ernst, K. (2011). Heart over mind-An empirical analysis of social entrepreneurial intention formation on the basis of the theory of planned behaviour. Unpublished dissertation, University Wuppertal.

Ferber, R. (1977). Research by convenience. Journal of Consumer Research, 4(1), 57-58.

Finney, S. J., \& DiStefano, C. (2006). Non-normal and categorical data in structural equation modeling. Structural equation modeling: A second course, 10(6), 269-314. 
Gallup Jr, G. G., \& Platek, S. M. (2002). Cognitive empathy presupposes self-awareness: Evidence from phylogeny, ontogeny, neuropsychology, and mental illness. Behavioral and Brain Sciences, 25(1), 36-37.

Goetz, J. L., Keltner, D., \& Simon-Thomas, E. (2010). Compassion: An evolutionary analysis and empirical review. Psychological Bulletin, 136(3), 351-374.

Goksel, A., \& Aydintan, B. (2011). The effect of leader-member exchange on organizational commitment: An empirical research. Suleyman Demirel University The Journal of Faculty of Economics and Administrative Sciences, 17(2), 247-271.

Hair, J. F., Black, W. C., Babin, B. J., Anderson, R. E., \& Tatham, R. L. (1998). Multivariate data analysis (Vol. 5, No. 3, pp. 207-219). Upper Saddle River, NJ: Prentice hall.

Handy, F., Ranade, B., \& Kassam, M. (2007). To profit or not to profit: Women entrepreneurs in India. Nonprofit Management and Leadership, 17(4), 383-401.

Hockerts, K. (2015). The social entrepreneurial antecedents scale (SEAS): A validation study. Social Enterprise Journal, $11(3), 260-280$.

Hockerts, K. (2017). Determinants of social entrepreneurial intentions. Entrepreneurship Theory and Practice, 41(1), $105-130$

Hossain, M. U., Asheq, A. A., \& Arifuzzaman, S. M. (2019). Entrepreneurial intention of Bangladeshi students: Impact of individual and contextual factors. Problems and Perspectives in Management, 17(4), 493-503.

Hsu, C. Y., \& Wang, S. M. (2019). Social entrepreneurial intentions and its influential factors: A comparison of students in Taiwan and Hong Kong. Innovations in Education and Teaching International, 56(3), 385-395.

Ip, C. Y., Liang, C., Wu, S. C., Law, K. M. Y., \& Liu, H. C. (2018). Enhancing social entrepreneurial intentions through entrepreneurial creativity: A comparative study between Taiwan and Hong Kong. Creativity Research Journal, 30(2), 132-142.

Kautonen, T., Luoto, S., \& Tornikoski, E. T. (2010). Influence of work history on entrepreneurial intentions in 'prime age'and 'third age': A preliminary study. International Small Business Journal, 28(6), 583-601.

Kedmenec, I., Rebernik, M., \& Peric, J. (2015). The impact of individual characteristics on intentions to pursue social entrepreneurship. Ekonomski Pregled, 66(2), 119-137.

Kelley, D., Singer, S., \& Herrington, M. (2016). Global Entrepreneurship Monitor: 2015/2016 Global Report. Global Entrepreneurship Research Association. Retrieved November 10, 2020, from www.gemconsortium.org.

Koh, H. C. (1996). Testing hypotheses of entrepreneurial characteristics: A study of Hong Kong MBA students. Journal of Managerial Psychology, 11(3), 12-25.

Krueger Jr, N. F., \& Brazeal, D. V. (1994). Entrepreneurial potential and potential entrepreneurs. Entrepreneurship Theory and Practice, 18(3), 91-104.

Krueger Jr, N. F., Reilly, M. D., \& Carsrud, A. L. (2000). Competing models of entrepreneurial intentions. Journal of Business Venturing, 15(5-6), 411-432.

Kutner, M. H., Nachtsheim, C. J., Neter, J., \& Li, W. (2005). Applied linear statistical models (Vol. 5). New York: McGrawHill Irwin.

Lacap, J. P. G., Mulyaningsih, H. D. \& Ramadani, V. (2018). The mediating effects of social entrepreneurial antecedents on the relationship between prior experience and social entrepreneurial intent: The case of Filipino and Indonesian university students. Journal of Science and Technology Policy Management, 9 (3), 329-346.

Macaskill, A., Maltby, J., \& Day, L. (2002). Forgiveness of self and others and emotional empathy. The Journal of Social Psychology, 142(5), 663-665.

Mair, J., Robinson, J., \& Hockerts, K. (Eds.). (2006). Social entrepreneurship (p. 3). Basingstoke: Palgrave Macmillan.

Mair, J., \& Noboa, E. (2006). Social entrepreneurship: How intentions to create a social venture are formed. In Social Entrepreneurship (pp. 121-135). Palgrave Macmillan, London.

Mander, Ü., Wiggering, H., \& Helming, K. (Eds.). (2007). Multifunctional land use: Meeting future demands for landscape goods and services. New York, NY: Springer.

Mazzarol, T., Volery, T., Doss, N. \& Thein, V. (1999). Factors influencing small business start-ups. International Journal of Entrepreneurial Behaviour \& Research, 5(2), 48-63.

Nasip, S., Amirul, S. R., Sondoh Jr, S. L., \& Tanakinjal, G. H. (2017). Psychological characteristics and entrepreneurial intention. Education+ Training, 59(7/8), 825-840. 
Nga, J. K. H., \& Shamuganathan, G. (2010). The influence of personality traits and demographic factors on social entrepreneurship start up intentions. Journal of Business Ethics, 95(2), 259-282.

Peng, X., Hassan, S., Akhtar, S., Sarwar, A., Khan, M. A., \& Khan, B. U. (2019). Determinants of social entrepreneurial intentions for educational programs. Journal of Public Affairs, 19(2), 1-11.

Preston, S. D., Bechara, A., Damasio, H., Grabowski, T. J., Stansfield, R. B., Mehta, S., \& Damasio, A. R. (2007). The neural substrates of cognitive empathy. Social Neuroscience, 2(3-4), 254-275.

Prieto, L. C. (2010). The influence of proactive personality on social entrepreneurial intentions among African American and Hispanic undergraduate students: The moderating role of hope. Retrieved December 10, 2020, from https://digitalcommons.Isu.edu/cgi/viewcontent.cgi?article=1316\&context=gradschool_dissertations

Razali, N. M., \& Wah, Y. B. (2011). Power comparisons of shapiro-wilk, kolmogorov-smirnov, lilliefors and andersondarling tests. Journal of statistical modeling and analytics, 2(1), 21-33.

Rotter, J. B. (1966). Generalized expectancies for internal versus external control of reinforcement. Psychological Monographs: General and Applied, 80(1), 1-28.

Sánchez, J. C. (2013). The impact of an entrepreneurship education program on entrepreneurial competencies and intention. Journal of Small Business Management, 51(3), 447-465.

Sharir, M., \& Lerner, M. (2006). Gauging the success of social ventures initiated by individual social entrepreneurs. Journal of World Business, 41, 6-20.

Sharma, S. (1996). Applied multivariate techniques (First Edition). New York. John Wiley \& Sons.

Shook, C. L., Priem, Richard, L., \& McGee, J. E. (2003). Venture creation and the enterprising individual: A review and synthesis. Journal of Management, 29(3), 379-399.

Smith, A. (2006). Cognitive empathy and emotional empathy in human behavior and evolution. The Psychological Record, 56(1), 3-21.

Souitaris, V., Zerbinati, S., \& Al-Laham, A. (2007). Do entrepreneurship programmes raise entrepreneurial intention of science and engineering students? The effect of learning, inspiration and resources. Journal of Business Venturing, 22(4), 566-591.

Sousa-Filho, J. M., Matos, S., da Silva Trajano, S., \& de Souza Lessa, B. (2020). Determinants of social entrepreneurial intentions in a developing country context. Journal of Business Venturing Insights, 14, 1-11.

Stewart Jr, W. H., Watson, W. E., Carland, J. C., \& Carland, J. W. (1999). A proclivity for entrepreneurship: A comparison of entrepreneurs, small business owners, and corporate managers. Journal of Business venturing, 14(2), $189-214$.

Stewart Jr, W. H., \& Roth, P. L. (2001). Risk propensity differences between entrepreneurs and managers: A metaanalytic review. Journal of Applied Psychology, 86(1), 145-153.

Thompson, E. R. (2009). Individual entrepreneurial intent: Construct clarification and development of an internationally reliable metric. Entrepreneurship Theory and Practice, 33(3), 669-694.

Tiwari, P., Bhat, A. K., \& Tikoria, J. (2017). The role of emotional intelligence and self-efficacy on social entrepreneurial attitudes and social entrepreneurial intentions. Journal of Social Entrepreneurship, 8(2), 165-185.

Tiwari, P., Bhat, A. K., Tikoria, J., \& Saha, K. (2019). Exploring the factors responsible in predicting entrepreneurial intention among nascent entrepreneurs. South Asian Journal of Business Studies, 9(1), 1-18.

Tracey, P., \& Phillips, N. (2007). The distinctive challenge of educating social entrepreneurs: A postscript and rejoinder to the special issue on entrepreneurship education. Academy of Management Learning \& Education, 6(2), 264271.

Vining, J., \& Ebreo, A. (1989). An evaluation of the public response to a community recycling education program. Society \& Natural Resources, 2(1), 23-36.

Vivarelli, M. (2013). Is entrepreneurship necessarily good? Microeconomic evidence from developed and developing countries. Industrial and Corporate Change, 22(6), 1453-1495.

Wijaya, T. (2019). Data survey on the antecedent of the entrepreneurial intention in Indonesia. Data in Brief, 25, 104317.

Yang, R., Meyskens, M., Zheng, C., \& Hu, L. (2015). Social entrepreneurial intentions: China versus the USA - Is there a difference? Entrepreneurship and Innovation, 16 (4), 253-267.

Yunus, O. M., Bank, G., Yunus, M., Prize, N. P., \& Bank, T. G. (2006). Concept paper on the bank of the poor - Grameen Bank microfinance system.

Yukongdi, V., \& Lopa, N. Z. (2017). Entrepreneurial intention: A study of individual, situational and gender differences. Journal of Small Business and Enterprise Development, 24(2), 333-352. 
This Page Intentionally Left Blank 